\title{
TOXIC EFFECTS OF LOCAL ANAESTHETICS ON HUMAN RESPIRATORY EPITHELIUM
}

\author{
Guenter Corssen, M.D.*
}

LOCAL ANAESTHETICS are considered "protoplasmic poisons." When used clinically their disturbing effect on cellular function is usually transient and reversible. For obvious reasons the clinical anaesthesiologist would like to know which local anaesthetic may be more hazardous than another with regard to possible toxic or irreversible effects.

Cultured ciliated epithelium of human bronchial or tracheal mucosa has proved to be most valuable in the study of toxic properties of local anaesthetics because the ciliary beat may serve as an index of cellular function. ${ }^{1}$

When electrolyte balance and other physiological factors such as optimal osmotic equilibrium and $\mathrm{pH}$ of the culture medium are maintained, cultures of human respiratory epithelium remain in a steady state for several days. Increased or decreased strength or rapidity of ciliary beat or disturbance of coordination of ciliary motion following exposure of the cells to various concentrations of local anaesthetic drugs may, therefore, be interpreted as a cytotoxic effect of the drug under study. The changes in cellular activity in response to the perfusion of the different local anaesthetic drugs can be objectively recorded by means of phasecontrast photomicrography and, particularly, with cinematography.

In order to prepare the tissue for the perfusion with the local anaesthetics the following steps are included:

Explants from punch biopsies of human tracheal and bronchial epithelium were cultivated in simple hanging drop preparations. After two to five days of incubation the tissue was transferred to a perfusion chamber and carefully sealed in with a mixture of paraffin and beeswax. The nutrient was introduced through an inlet tube, passed across the central area containing the ciliated cells and removed through a capillary outlet tube. The chamber was placed on a stage of a microscope and effects recorded by cinematography at a rate of sixteen frames per second.

Under conditions in which liquefaction of the clotted medium occurred, small epithelial explants curled up to form globes with their cilia on their outside surface. These cell clusters which rotated for several days at a relatively uniform rate, were transferred into the perfusion chamber filled with Gey's balanced salt solution. The rotating clusters were allowed to stabilize until rotational movements persisted at the same speed. The number of rotations per minute was clocked with a stopwatch.

Local anaesthetic solutions to be perfused through the chamber were prepared by dissolving the crystals of each drug in the balanced salt solution. It was possible to determine for each local anaesthetic under observation the concentration which

*Birmingham, Alabama.

Canad. Anaesth. Soc. J., vol. 20, no. 1, January 1973 
(a) did not affect ciliary activity, $(b)$ caused persistent stimulation, $(c)$ stopped ciliary motility but, after reperfusion with the balanced salt solution, resulted in revival of the tissue, and $(d)$ arrested ciliary action with permanent cell injury so that reperfusion with the balanced solution failed to reactivate the ciliary beat.

The table presents a comparison of the effects of six clinically employed local anaesthetic drugs on the cultured ciliated epithelium.

Procaine ( 0.05 per cent) and lidocaine ( 0.01 per cent) had no visible effect on ciliary function. At 0.1 per cent both drugs caused persistent stimulation, while temporary loss of ciliary motility was observed with procaine and lidocaine in concentrations ranging from 5 per cent to 20 per cent.

Chloroprocaine did not affect the ciliary beat at a concentration of 0.005 per cent. The drug began to exhibit a stimulatory action at 0.01 per cent and caused ciliary arrest at concentrations ranging from 0.5 per cent to 3.0 per cent.

Perfusion with tetracaine and dibucaine showed no effect on ciliary movement at concentrations up to 0.001 per cent (dibucaine) and up to 0.01 per cent (tetracaine), while the first stimulating response was noted with dibucaine at 0.003 per cent and with tetracaine at 0.015 per cent. With solutions of tetracaine 0.15 per cent or dibucaine 0.1 per cent a rapid decrease and subsequent stopping of the ciliary action was observed. Ciliary action failed to return when the balance salt solution was reperfused.

Cocaine accelerated rotary activity of the epithelial cell mass at concentrations of 0.1 per cent to 0.5 per cent while a 10 per cent solution arrested ciliary action, usually with incomplete recovery. Cocaine at a concentration of 20 per cent rendered the cell damage irreversible.

Chloroprocaine and lidocaine caused a considerably more rapid onset of the inhibitory effect as compared to procaine, cocaine, tetracaine, and dibucaine.

At effective concentrations procaine, chloroprocaine, lidocaine, and cocaine caused a peculiar vibration of the whole tissue which was not observed with tetracaine and dibucaine.

The intensity with which the local anaesthetic agent affected cell function appeared to differ significantly with various agents. Procaine, chloroprocaine and lidocaine had a remarkably wide range of discernible effect on cell activity without causing permanent damage to the cell. None of these three drugs at clinically useful concentrations was observed to render the complete ciliary arrest irreversible. In contrast to this group, tetracaine and dibucaine not only stopped ciliary action at considerably lower concentrations but appeared to have a markedly smaller margin of safety between their least effective concentrations and those causing irreversible damage to the tissue. Permanent cell damage with signs of disintegration of the epithelial mass occurred with tetracaine at 0.15 per cent and with dibucaine at 0.1 per cent, which are concentrations commonly used for producing regional anaesthesia in man.

The onset of the inhibitory effect upon cellular activity was observed to be almost twice as fast with chloroprocaine and lidocaine as compared to procaine, cocaine, tetracaine and dibucaine. The considerably faster manifestation of cellular depression and the more prompt reversibility of the effect noted with chloroprocaine and lidocaine suggested a higher diffusibility and penetrating power of these agents in comparison to procaine, cocaine, tetracaine, and dibucaine. 


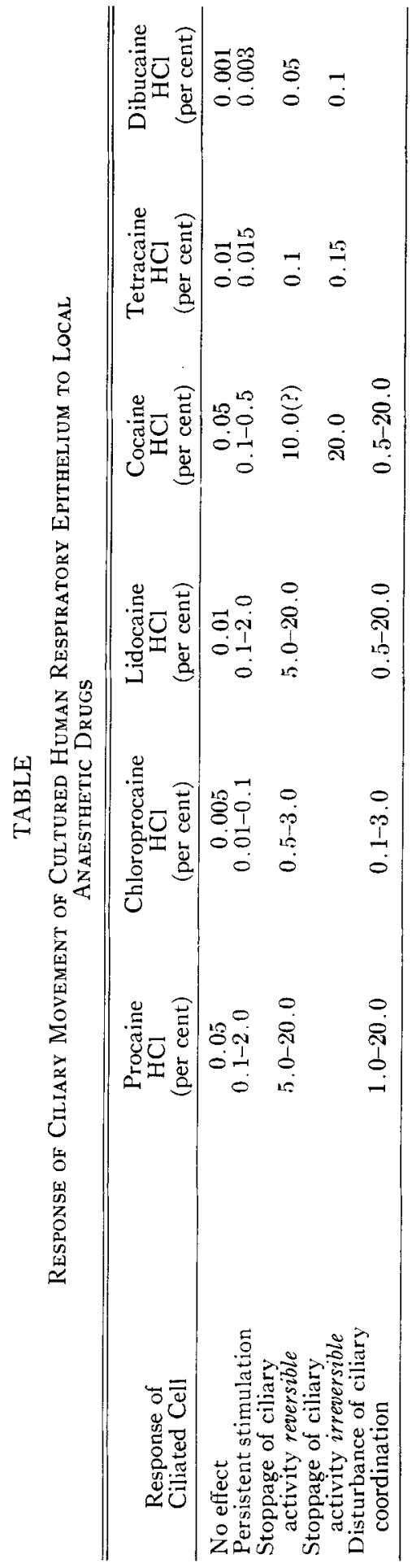


The peculiar trembling and shaking of the whole tissue seen with procaine, chloroprocaine, lidocaine and cocaine at certain concentrations was believed to represent a disturbance in the mechanism of ciliary coordination. Perfusions with tetracaine and dibucaine failed to show this unusual phenomenon.

\section{RÉSUMÉ}

Des cultures d'épithélium humain respiratoire cilié obtenu de la trachée et des bronches ont été utilisées pour étudier les effets des anesthésiques locaux sur la cellule. Le mouvement ciliaire qui est demeuré inchangé lorsque le prélèvement d'épithélium respiratoire a été transporté dans une solution salée équilibrée a servi d'indicateur de l'activité cellulaire. L'épithélium mis en contact avec différentes concentrations d'anesthésiques locaux, son activité ciliaire a subi des changements tels : l'accélération, la décélération, l'arrêt ou des troubles de la coordination du mouvement ciliaire. L'effet a été soit réversible ou a causé un dommage permanent à la cellule.

On s'est servi de cette méthode pour faire une étude comparative de la procaine, de la chloroprocaine, de la lidocaine, de la cocaine, de la tétracaine et de la dibucaine. La faible toxicité et le remarquablement large spectre d'efficacité de la procaine, de la chloroprocaine et de la lidocaine sur la cellule cultivée ont été significatifs. Aux concentrations cliniques utiles, aucun de ces trois anesthésiques n'a produit de dommage permanent.

La tétracaine et la dibucaine se sont avérées d'une toxicité beaucoup plus considérable pour les cellules. La marge d'activité sans causer de dommage permanent à la cellule a été beaucoup plus étroite et l'activité cellulaire est devenue irréversible à des concentrations employées couramment pour produire des anesthésies régionales chez l'homme.

La cocaine semble occuper une place entre les deux groupes mentionnés.

Le début d'action du médicament qui se manifestait par l'arrêt ciliaire et la reversibilité du procédé avec retour complet du mouvement ciliaire ont été presque deux fois plus rapides avec les perfusats à la chloroprocaine et à la lidocaine comparés aux effets de la procaine, de la cocaine, de la tétracaine et de la dibucaine. Ces observations font croire à une plus grande diffusibilité et à un plus grand pouvoir de pénétration de la chloroprocaine et de la lidocaine.

\section{REFERENCE}

1. Crossen, G. \& Allen, C.R. Cultured Human Respiratory Epithelium: Its Use in the Comparison of the Cytotoxic Properties of Local Anesthetics. Anesthesiology 21: 237-243, 1960. 